\title{
Cellular Basis for the Negative Inotropic Effects of Tumor Necrosis Factor- $\alpha$ in the Adult Mammalian Heart
}

\author{
Tomoyuki Yokoyama, Luis Vaca, Roger D. Rossen, William Durante, Parul Hazarika, and Douglas L. Mann \\ Cardiology and Immunology Sections, Department of Medicine, Departments of Molecular Physiology and Biophysics and Microbiology \\ and Immunology, Veterans Affairs Medical Center and Baylor College of Medicine, Houston, Texas 77030
}

\begin{abstract}
To define the mechanism( $\mathrm{s}$ ) responsible for the negative inotropic effects of tumor necrosis factor- $\alpha(\mathrm{TNF} \alpha)$ in the adult heart, we examined the functional effects of TNF $\alpha$ in the intact left ventricle and the isolated adult cardiac myocyte. Studies in both the ventricle and the isolated adult cardiac myocyte showed that TNF $\alpha$ exerted a concentration- and time-dependent negative inotropic effect that was fully reversible upon removal of this cytokine. Further, treatment with a neutralizing anti-TNF $\alpha$ antibody prevented the negative inotropic effects of TNF $\alpha$ in isolated myocytes. A cellular basis for the above findings was provided by studies which showed that treatment with TNF $\alpha$ resulted in decreased levels of peak intracellular calcium during the systolic contraction sequence; moreover, these findings did not appear to be secondary to alterations in the electrophysiological properties of the cardiac myocyte. Further studies showed that increased levels of nitric oxide, de novo protein synthesis, and metabolites of the arachidonic acid pathway were unlikely to be responsible for the TNF $\alpha$-induced abnormalities in contractile function. Thus, these studies constitute the initial demonstration that the negative inotropic effects of TNF $\alpha$ are the direct result of alterations in intracellular calcium homeostasis in the adult cardiac myocyte. ( J. Clin. Invest. 1993. 92:2303-2012.) Key words: calcium • contractility • cytokine $\bullet$ myocyte $\bullet$ tumor necrosis factor- $\alpha$
\end{abstract}

\section{Introduction}

An increasing body of experimental and clinical evidence now suggests that certain pro-inflammatory cytokines play an important role in a variety of cardiac pathophysiological conditions. TNF $\alpha$ is a pro-inflammatory cytokine that was originally discovered as a protein with necrotizing effects in certain transplantable mouse tumors (1). More recently, however, this cytokine has been shown to exert a spectrum of pleiotropic effects in different cell types. Although the major biological role for TNF $\alpha$ is thought to be as a host response to systemic infections, most notably gram-negative sepsis, this cytokine has also been implicated in a variety of cardiac disease states that are not considered to be attributable to bacterial infections, including acute viral myocarditis (2), cardiac allograft rejection (3), myocardial infarction $(4,5)$, and congestive heart failure $(6,7)$.

Address reprint requests to Dr. Douglas L. Mann, Cardiology Section, VA Medical Center, 2002 Holcombe Blvd., Houston, TX 77030.

Received for publication 5 November 1992 and in revised form 3 June 1993.

The Journal of Clinical Investigation, Inc.

Volume 92, November 1993, 2303-2312
Previous experimental and clinical studies have suggested that there is an association between depressed myocardial function and elevated levels of TNF $\alpha(8-14)$. However, the exact mechanism(s) for any potential TNF $\alpha$-induced effects in the intact heart is (are) not known. Moreover given the complexity of the aforementioned pathophysiological conditions, as well as the intricate admixture of cell types in the heart, each of which may respond differently to the pleiotropic effects of TNF $\alpha$, it has not been possible to determine whether TNF $\alpha$ has a direct effect on the cardiac myocyte itself, or whether instead this cytokine exerts its effect(s) indirectly, by releasing one or more soluble factors from nonmyocyte cell types residing within the myocardium.

The purpose of this study was to provide a focused approach toward defining the acute mechanism(s) of action of TNF $\alpha$ in the heart. Accordingly, in the present study we systematically examined the functional effects of TNF $\alpha$ in vitro both at the tissue and cellular levels. Additional studies were subsequently performed to further delineate the basic cellular and molecular mechanism(s) of action for TNF $\alpha$. The results of the present study support the point of view that the negative inotropic effects of TNF $\alpha$ are the direct result of alterations in intracellular calcium homeostasis in the adult cardiac myocyte.

\section{' Methods}

\section{Effects of TNF $\alpha$ on myocardial function}

Myocardial function was assessed using a modified Langendorff preparation. Briefly, adult cats weighing $2.9-4.3 \mathrm{~kg}$ were anesthetized with ketamine hydrochloride ( $50 \mathrm{mg} / \mathrm{kg}$ i.m.) and acepomazine maleate ( 5 $\mathrm{mg} / \mathrm{kg}$ i.m.), the hearts were rapidly excised and perfused at a constant rate of $35 \mathrm{ml} /$ minute using a bilateral roller pump (15). The coronary superfusate consisted of a nonrecirculating Krebs-Henseleit buffer (KHB ${ }^{1}$ solution of the following composition $(\mathrm{mM}): \mathrm{NaCl} 118.0, \mathrm{KCl}$ 4.0, $\mathrm{MgCl}_{2} \cdot \mathrm{H}_{2} \mathrm{O}$ 1.2, $\mathrm{KH}_{2} \mathrm{PO}_{4} 1.1, \mathrm{CaCl}_{2} \cdot 2 \mathrm{H}_{2} \mathrm{O} 2.4, \mathrm{NaHCO}_{3} 25.0$, glucose 5.0, L-glutamate $5.0(\mathrm{pH} \mathrm{7.4)}$. The solution was oxygenated with $95 \% \mathrm{O}_{2}$ and $5 \% \mathrm{CO}_{2}$ and maintained at $37^{\circ} \mathrm{C}$ by a jacketed water bath. Coronary perfusion pressure was set at $75 \mathrm{mmHg}$ and remained constant throughout the course of the studies. In order to produce a closed system in which the effluent drainage from the coronary arteries and the left ventricle (LV) would not be recirculated, the pulmonary veins and vena cavae were ligated, the pulmonary artery was cannulated and the LV was drained through the left atrium. Developed LV pressure was measured by means of a fluid-filled latex balloon connected to a pressure transducer. The hearts were paced electrically at $2.2 \mathrm{~Hz}$ via the right atrium using a bipolar platinum electrode. All hearts were allowed to equilibrate for $30 \mathrm{~min}$ before the time of study.

Following the above equilibration period, a series of four separate 30-min protocols were performed. The composition of the buffer solution superfusing the heart was varied by injecting either diluent ( $1 \%$

1. Abbreviations used in this paper: KHB, Krebs-Henseleit buffer; LV, left ventricle. 
BSA) or TNF $\alpha$ (with $1 \%$ BSA) into a side-arm port above the heart, such that the injectate mixed thoroughly with the coronary superfusate solution. The flow rate of the injected solution was controlled precisely by a roller-pump and remained constant at $1.8 \mathrm{ml} / \mathrm{min}$; the flow rate of the KHB coronary superfusate was adjusted downward accordingly, such that the total combined total flow rate of coronary superfusate and injectate always remained constant at $35 \mathrm{ml} / \mathrm{min}$. Control measurements were obtained during infusion of diluent for $30 \mathrm{~min}$; experimental measurements were obtained during infusion of $10 \mathrm{U} / \mathrm{s}$ TNF $\alpha$ $(\sim 17 \mathrm{U} / \mathrm{ml} / \mathrm{min})$ for $30 \mathrm{~min}$, followed by $50 \mathrm{U} / \mathrm{s} \mathrm{TNF} \alpha(\sim 86 \mathrm{U} /$ $\mathrm{ml}$ per min) for $30 \mathrm{~min}$. To assess the reversibility of any TNF $\alpha$ induced effects, the hearts were perfused with diluent for $30 \mathrm{~min}$ during the final protocol.

At the start of each of the four protocols the $\mathrm{LV}$ balloon volume was adjusted to achieve an end-diastolic pressure of $10 \mathrm{mmHg}$, and the developed $\mathrm{LV}$ pressure $(\mathrm{mmHg})$ and $\mathrm{LV} \mathrm{d} P / \mathrm{d} T(\mathrm{mmHg} / \mathrm{s})$ recorded at intervals of $0,5,10,15,20$, and $25 \mathrm{~min}$. After $25 \mathrm{~min}$ of continuous infusion, the LV balloon volume was adjusted to achieve end-diastolic pressures of $0,5,10,15$, and $20 \mathrm{mmHg}$ : developed $\mathrm{LV}$ pressure was then measured for each level of end-diastolic pressure in order to establish a LV function curve. The total duration for each experiment did not exceed $2.5 \mathrm{~h}$, during which time the experimental preparation was quite stable.

\section{Cardiocyte isolation}

The morphological, meabolic, mechanical, and electrophysiological properties of the cardiocytes used in this study have been described previously (16-18). The methods for isolating reproducible yields of calcium-tolerant cardiac myocytes have been reported previously in considerable detail (19-21).

\section{Cardiocyte mechanics}

To determine whether TNF $\alpha$ had a direct effect on the contractility of the adult cardiocyte, cardiocyte motion was characterized using videoedge detection system (22) that measures changes in cell length as a function in time. To reduce the noise inherent in a single contraction sequence, the velocity of shortening was determined as the average of 10 successive beats. The change in cell length as a function of time was then used to derive the extent and peak velocity of cell shortening.

\section{Cardiocyte evaluation}

Effects of TNF $\alpha$ on cardiocyte viability. Given the well-described cytotoxic effects of TNF $\alpha$ on tumoral cell lines $(23,24)$, we considered it important to determine whether TNF $\alpha$ was acutely cytotoxic to adult cardiocytes. Accordingly, freshly isolated cardiocytes were treated for 6 h with $200 \mathrm{U} / \mathrm{ml}$ of TNF $\alpha$, and cardiocyte viability measured both in terms of indices of necrotic cell death and apoptotic cell death. Three indices of necrotic cell death were examined: the percentage of quiescent rod-shaped cells in 10 randomly chosen $1 \times 1$-mm field, the percentage of rod-shaped cells in 10 randomly chosen $1 \times 1-\mathrm{mm}$ fields excluding $0.4 \%$ trypan blue, and the quantitative release of creatine kinase into the medium after $6 \mathrm{~h}$ of exposure to TNF $\alpha(21)$. The presence or absence of nucleosome laddering was taken as evidence for TNF $\alpha$-induced apoptotic cell death (23). Cultures of freshly isolated cardiocytes were incubated with diluent or $200 \mathrm{U} / \mathrm{ml} \mathrm{TNF} \alpha$ for $6 \mathrm{~h}$, after which DNA was isolated according to the method of Blin and Stafford (25). DNA ( $5 \mu \mathrm{g}$ ) from control and TNF $\alpha$-treated cells was loaded into the dry wells of a $2 \%(\mathrm{wt} / \mathrm{vol}$ ) agarose gel containing 0.1 $\mu \mathrm{g} / \mathrm{ml}$ ethidium bromide. Electrophoresis was carried out in $10 \mathrm{mM}$ Tris- $\mathrm{HCl}$ and $1 \mathrm{mM}$ EDTA at $30 \mathrm{~V}$ until the marker dye had migrated $5-6 \mathrm{~cm}$.

Effects of TNF $\alpha$ on cardiocyte contractility. Freshly isolated cells were allowed to equilibrate for $1 \mathrm{~h}$ in a pH 7.4 buffer solution of the following composition (mM): $\mathrm{NaCl} 120, \mathrm{KCl} 5.8, \mathrm{NaHCO}_{3} 4.3, \mathrm{CaCl}_{2}$ 2.5, $\mathrm{MgSO}_{4} 1.5, \mathrm{KH}_{2} \mathrm{PO}_{4} 1.4$, dextrose 10.0, and 10.0. After this equilibration period the cells $\left(2 \times 10^{5}\right.$ cells $\left./ \mathrm{ml}\right)$ were placed in KHB buffer with $1 \%$ BSA, and treated for $30 \mathrm{~min}$ with $50-200 \mathrm{U} / \mathrm{ml}$ of TNF $\alpha(6)$; control cardiocytes were treated with an equal volume of diluent $(1 \%$
BSA). After treatment with TNF $\alpha$, an aliquot of cardiocytes was placed in a plastic chamber resting on the stage of an inverted microscope; the temperature of the KHB buffer solution in the plastic chamber was maintained at $35^{\circ} \mathrm{C}$ by a heated stage. A pair of platinum wire electrodes was used to stimulate the cells using $0.25 \mathrm{~Hz}, 100-\mu \mathrm{A}$ DC pulses of alternating polarity with no voltage offset between pulses (20).

After the amount of shortening appeared stable (generally 10-15 beats), 10 contractions were sampled and averaged to yield a final profile of cell length versus time during contraction. Only cells with the following characteristics were analyzed: single, rod-shaped cells, unattached to either adjacent cells or debris, which contracted with each stimulus and which were quiescent between stimuli. We examined the peak velocity of cell shortening $(\mu \mathrm{m} / \mathrm{s})$ and the peak extent of sarcomere shortening (percent change).

To characterize the effects on TNF $\alpha$ further, two additional experiments were performed. First, to determine the time course of the TNF $\alpha$-induced effects, cardiocytes were exposed continuously to 200 $\mathrm{U} / \mathrm{ml}$ of TNF $\alpha$ and cell motion measured at 5, 10, 15, 20, and $25 \mathrm{~min}$ after treatment. To confirm that TNF $\alpha$ was directly responsible for the decreased cardiocyte contractility, a solution of $200 \mathrm{U} / \mathrm{ml} \mathrm{TNF} \alpha$ was preincubated for $60 \mathrm{~min}$ with $1.0 \mu \mathrm{l} / \mathrm{ml}$ of neutralizing polyclonal rabbit anti-human TNF $\alpha$ antibody, and then centrifuged at $12,500 \mathrm{~g}$. The supernatant was then applied to a fresh suspension of cardiocytes for 30 min and cardiocyte contractility characterized as described above. To assess the reversibility of any TNF $\alpha$-induced effects, cardiocytes were first treated with $200 \mathrm{U} / \mathrm{ml}$ of TNF $\alpha$ for $30 \mathrm{~min}$ and then washed three times with KHB buffer solution; the cells were then allowed to recover for $45 \mathrm{~min}$ before reassessing cell motion.

\section{Cellular basis for the effect of TNF $\alpha$ on cardiocyte contractility}

Calcium homeostasis. Three experiments were performed to delineate the cellular mechanism of the TNF $\alpha$-induced contractile dysfunction in isolated cardiac myocytes. First, to determine whether altered calcium responsivity of the TNF $\alpha$-treated cells was responsible for the observed contractile dysfunction, the extent of cardiocyte shortening was examined for cells treated with $200 \mathrm{U} / \mathrm{ml}$ of TNF $\alpha$ for $30 \mathrm{~min}$, and then exposed to graded calcium concentrations ranging from 1 to 7.5 $\mathrm{mM}$; control cells were treated with diluent only.

Second, to test whether alterations in $\left[\mathrm{Ca}^{2+}\right]_{\mathrm{i}}$ were responsible for the TNF $\alpha$-induced effect, we measured intracellular calcium transients in isolated contracting cardiocytes using the fluorescent indicator fluo3 , as we have described previously (21). After $30 \mathrm{~min}$ of loading with fluo-3 $(20 \mu \mathrm{M})$, the cells were treated with $200 \mathrm{U} / \mathrm{ml}$ of TNF $\alpha$; control cells were treated with diluent. In a separate set of control experiments we also examined fluorescent brightness over time in the same cell, both before and after treatment with TNF $\alpha$. After loading, the cells were washed gently three times to remove any unincorporated fluo-3, and then placed in a plastic chamber and stimulated at $0.25 \mathrm{~Hz}$ as described above. Fluorescence brightness was recorded at baseline and then continually during the myocyte contraction sequence using a microspectrofluorimeter equipped with a xenon bulb, an image intensifier, and a charge-coupled device camera. The filter sets employed herein delivered 450-490-nm excitation light; emission was measured using a barrier filter that passed light at wavelengths $520-560 \mathrm{~nm}$. The resulting fluorescence images $(\times 400)$ were recorded on videotape, and the data were subsequently analyzed frame by frame $(16.7 \mathrm{~ms})$ using digital imaging microscopy. A time-intensity curve for fluorescence brightness was determined for a single cardiocyte contraction by measuring the total fluorescence brightness over the surface area of individual cells; all fluorescent measurements were obtained after cardiocyte contraction had stabilized. In preliminary control experiments we established that treatment with TNF $\alpha(50-200 \mathrm{U} / \mathrm{ml})$ did not result in changes in baseline intracellular fluorescent brightness over a 30-min period of observation. Data were, therefore, expressed in terms of the percent change from baseline values in total cellular fluorescent brightness. As an additional control experiment, we also examined changes 
in fluorescence brightness in the same cell, before and after treatment with TNF. For these studies, cells were loaded with fluo-3 and stimulated to contract as described above. Measurements of intracellular fluorescence brightness were then obtained for individual cells at baseline and $30 \mathrm{~min}$ after treatment with TNF $(200 \mathrm{U} / \mathrm{ml})$.

Third, to determine whether the TNF $\alpha$-induced contractile dysfunction was the result of a defect in cross-bridge activation, the extent of cell shortening was examined under conditions which we have shown to produce tetanus in isolated feline cardiocytes (20). The extent of cell shortening was recorded on videotape and stored for playback; cardiocyte resting length and length at peak shortening were measured by edge detection.

Electrophysiology. To determine whether the effects of TNF $\alpha$ might be secondary to alterations in the inward calcium current, we used the whole-cell patch-clamp technique to measure the current-voltage relationship in isolated cardiac myocytes (26). Freshly isolated single cardiac myocytes were studied in KHB buffer maintained at room temperature. The pipette resistance was 2-8 $\mathrm{M} \Omega$ when filled with the intracellular solution $(\mathrm{mM}): 150 \mathrm{~K}$-aspartate, $5 \mathrm{NaCl}, 10 \mathrm{Hepes}, 1$ $\mathrm{MgCl}_{2}$, and 5 EGTA and $0.1 \mathrm{CaCl}_{2}$. In the whole-cell configuration baseline measurements of whole cell current (protocol below) were obtained every minute for 5 min during perfusion with KHB using a gravity-driven multibarrel perfusion system. After establishing that the calcium current was stable, TNF $\alpha(200 \mathrm{U} / \mathrm{ml})$ in $\mathrm{KHB}$ was applied to the myocytes $(n=12)$ via the perfusion system; measurements were obtained in the presence of TNF $\alpha$ every $2 \mathrm{~min}$ for a total of 15-20 min. Five of the cells were then reperfused with TNF $\alpha$-free KHB buffer and repeat measurements obtained in KHB solution for an additional 10 $20 \mathrm{~min}$. The reference electrode used was an $\mathrm{Ag}-\mathrm{AgCl}$ plug connected to the bath solution via a $150 \mathrm{mM} \mathrm{KCl}$ agar bridge. The voltage protocol used to identify the calcium current was as follows. The membrane potential was held at $-90 \mathrm{mV}$. A depolarizing prepulse of $1.2 \mathrm{~s}$ in duration to $-40 \mathrm{mV}$ was used to inactivate the sodium current. This was followed by a series of step polarizations in $20-\mathrm{mV}$ increments from -120 to $+40 \mathrm{mV}$. Data was filtered at $2 \mathrm{KHz}$ and digitized at 200 $\mu \mathrm{s} /$ point. Current-voltage relationships were analyzed suing pClamp software (Axon Instruments Inc., Burlingame, CA)

\section{Molecular basis of the effect of TNF $\alpha$ on cardiocyte contractility}

Four experiments were performed to delineate the immediate molecular basis for the TNF $\alpha$-induced effect on cardiocyte contractility. To determine whether an increase in synthesis of nitric oxide was important in terms of mediating the acute negative inotropic effects of TNF $\alpha$, as has been suggested recently for thin strips of myocardial tissue (27), a series of three interrelated experiments were conducted. First, two different inhibitors of nitric oxide synthase were employed in order to attenuate the TNF $\alpha$-induced contractile dysfunction in isolated cardiocytes. Briefly, freshly isolated cells were pretreated for $1 \mathrm{~h}$ with $\mathrm{N}^{\mathrm{G}}$ methyl-L-arginine (range $10-1,000 \mu \mathrm{M}$ ) or $\mathrm{N}^{\mathrm{G}}$-nitro-L-arginine (range $10-1,000 \mu \mathrm{M})(28,29)$ before stimulation ( $30 \mathrm{~min}$ ) with $200 \mathrm{U} / \mathrm{ml}$ TNF $\alpha$; control cells were treated for an equivalent period of time with diluent. Second, we measured the oxidation of nitric oxide, whose halflife is on the order of seconds (30), by determining nitrite levels in diluent and TNF $\alpha$-treated cultures. Nitrite production was determined by diazotation and absorbance reading at $540 \mathrm{~nm}(31)$. The sensitivity of this technique is $200 \mathrm{pmol} / \mathrm{ml} \mathrm{(31)}$. Briefly, cells were incubated in KHB buffer and treated with $200 \mathrm{U} / \mathrm{ml} \mathrm{TNF} \alpha$ for $30 \mathrm{~min}$ or $6 \mathrm{~h}$. The cells were then centrifuged and the pellet measured for total cardiocyte protein using the bicinchoninic assay (32). Cell-free aliquots $(400 \mu \mathrm{l})$ of supernatant were mixed with an equal volume of $1 \%$ sulfanilamide$0.1 \% N$-[1-naphthyl] ethylenediamine dihydrochloride in $2 \%$ phosphoric acid (Greiss reagent) at room temperature for $10 \mathrm{~min}$. All nitrite concentrations were determined relative to a standard curve, which was obtained using an aqueous solution of sodium nitrite as a standard; the values obtained for control and TNF $\alpha$-stimulated cells were bracketed by standard values. All values were background corrected for nitrite values obtained in nonconditioned KHB buffer. Data were ex- pressed as nanograms of nitrite per milligram of cardiocyte protein. Third, since the effects of nitric oxide are thought to be mediated by cGMP, we measured levels of cGMP using a commercially available kit (Amersham Corp., Arlington Heights, IL). For these studies, cardiocytes were maintained in culture for $24 \mathrm{~h}$ as we have described previously (21), and then stimulated with $200 \mathrm{U} / \mathrm{ml} \mathrm{TNF} \alpha$ for 0,15 , and 30 $\mathrm{min}$. At the end of each time period, cyclic nucleotides were extracted for 5 min using cold $0.1 \mathrm{~N} \mathrm{HCl}$ (21). For these latter studies, sodium nitroprusside $(100 \mu \mathrm{M})$ was used as a positive control. Data were expressed as femtomoles cGMP per microgram of cardiocyte protein.

Three additional experiments were performed to delineate a possible molecular basis for the TNF $\alpha$-induced effect on cardiocyte contractility. Inasmuch as previous reports have suggested that de novo protein synthesis $(33)$ or arachidonic acid $(34,35)$ metabolism might be important in terms of mediating some of the effects of TNF $\alpha$, we measured cell motion after pretreating the cell cultures $\left(2 \times 10^{5}\right.$ cells $\left./ \mathrm{ml}\right)$ for $1 \mathrm{~h}$ with $2 \times 10^{-5} \mathrm{M}$ cycloheximide (19), $100 \mu \mathrm{M}$ indomethacin (36) or for 1 or $5 \mathrm{~h}$ with $10^{-6} \mathrm{M}$ hydrocortisone. For these studies, hydrocortisone and indomethacin were dissolved in ethyl alcohol; the final concentration of ethyl alcohol used was $0.01 \%$ and $0.1 \%$, respectively, for the hydrocortisone and indomethacin studies. To be certain that the concentration of ethyl alcohol used in these studies would not affect cardiocyte contractility adversely, in preliminary control experiments we established that $\leq 0.1 \%$ ethyl alcohol did not affect cardiocyte motion significantly. After treatment with cycloheximide, indomethacin, or hydrocortisone, cardiocyte cultures were treated with 200 $\mathrm{U} / \mathrm{ml}$ of TNF $\alpha$ for $30 \mathrm{~min}$ and cardiocyte contractility was assessed as described above; control cultures were handled identically with the exception that they were treated with diluent only. Data were expressed in terms of the percent change in cardiocyte shortening compared with control values. Finally, to determine whether TGF $\beta$ was capable of attenuating the TNF $\alpha$-induced effects on cardiocyte contractile dysfunction, as has been suggested by a recent study in vivo (5), freshly isolated cells were treated for 1 or $5 \mathrm{~h}$ with TGF $\beta$ (range $1-100 \mathrm{ng} / \mathrm{ml}$ ) and then treated with $200 \mathrm{U} / \mathrm{ml}$ TNF $\alpha$ for $30 \mathrm{~min}$; control cells were treated with $100 \mathrm{ng} / \mathrm{ml}$ TGF $\beta$. Cell motion was then characterized as described above.

\section{Materials}

Recombinant human TNF $\alpha$ (Genzyme Corp., Cambridge, MA) was used throughout these studies; a rabbit polyclonal anti-human TNF $\alpha$ antibody was used to neutralize the effects of TNF $\alpha$ (Genzyme Corp.). The source for the chemicals utilized in these experiments were as follows: tissue culture grade chemicals for buffer solutions, BSA, indomethacin, cycloheximide, sodium nitroprusside, $\mathrm{N}^{\mathrm{G}}$-methyl-L-arginine, phenol, ethidium bromide, caffeine, and sulfanilamide- $0.1 \%$ $N$-[1 napthyl ]ethylene-diamine dihydrochloride (Sigma Chemical Co., St. Louis, MO); TGF $\beta$ (Genzyme Corp.); hydrocortisone (Collaborative Research, Waltham, MA), $\mathbf{N}^{\mathrm{G}}$-nitro-L-arginine (Aldrich Chemical Co., Milwaukee, WI), fluo-3 and pluronic F-127 (Molecular Probes Inc., Eugene, OR); RNase and proteinase K (Boehringer-Manheim Biochemicals, Indianapolis, IN). Cyclic GMP was measured using a commercially available kit (Amersham Corp.).

\section{Statistical analysis}

Each value is expressed as a mean $\pm \mathrm{SE}$. Nonpaired $t$ tests were used to evaluate mean differences in cardiocyte motion for cells treated with one or more inhibitors, either in the presence and absence of a single concentration of TNF $\alpha$. Paired $t$ tests were used to evaluate mean differences in the peak inward calcium current. One-way analysis of variance was used to evaluate differences in the peak extent of cardiocyte shortening in the presence of varying concentrations of TNF $\alpha$. Twoway analysis of variance was used to evaluate differences between and within groups in peak developed $\mathrm{LV}$ pressure, peak $\mathrm{LV} \mathrm{d} P / \mathrm{d} T$ in the presence or absence of varying concentrations of TNF $\alpha$, differences in the extent of cardiocyte shortening in the presence of varying concentrations of superfusate calcium, or differences in the current-voltage relationship in the presence and absence of TNF $\alpha$. Where appropriate, 
post-hoc multiple comparison testing was performed (Dunnett's) to test for differences between control and experimental groups. Significant differences were said to exist at $P<0.05$.

\section{Results}

\section{Effects of TNF $\alpha$ on myocardial function}

Panels $A$ and $B$ of Fig. 1 show, respectively, the results of the studies wherein the percent change in peak developed LV systolic pressure or the percent change in peak $\mathrm{LV} \mathrm{d} P / \mathrm{d} T$ were examined after treatment with diluent or TNF $\alpha$ ( 10 and 50 $U / s)$. As shown, there was no significant change in either the peak developed systolic pressure or the peak $\mathrm{d} P / \mathrm{d} T$ pressure during infusion with diluent or the lower concentration of TNF $\alpha$. In contrast, there was a significant decrease in both the peak developed pressure $(P<0.032)$ and the peak $\mathrm{d} P / \mathrm{d} T(P$ $<0.002$ ) after treatment with $50 \mathrm{U} / \mathrm{s}$ of TNF $\alpha$; post-hoc analysis of variance indicated that these changes were significantly $(P<0.05)$ different from control values by $20 \mathrm{~min}$ of treatment. Two-way analysis of variance showed that the values for peak developed LV pressure and peak $\mathrm{d} P / \mathrm{d} T$ were signifi-
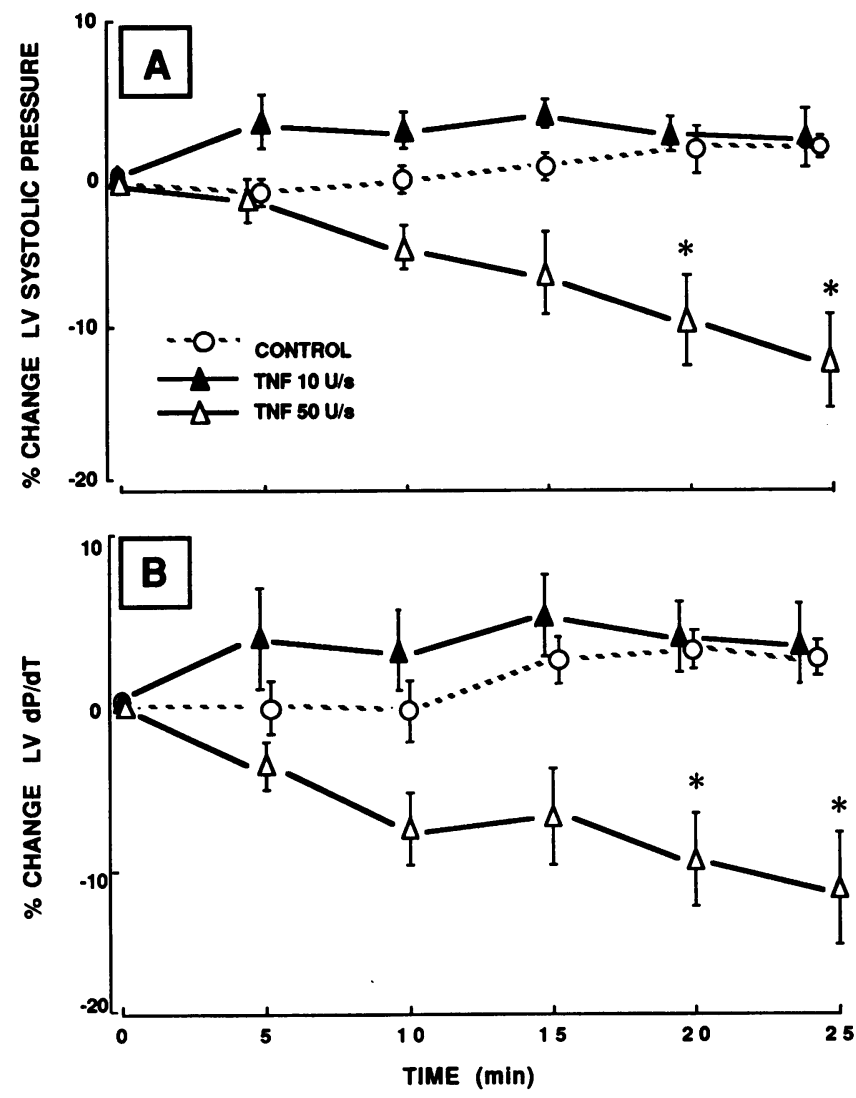

Figure 1. Effect of TNF $\alpha$ on LV function ( $n=6$ hearts). ( $A$ ) Effect of varying concentrations of TNF $\alpha$ on peak developed LV pressure. In comparison with control values, there was a significant decrease in peak developed LV pressure for $50 \mathrm{U} / \mathrm{s} \mathrm{TNF} \alpha(P<0.002)$, but not for diluent $(P=0.30)$ or $10 \mathrm{U} / \mathrm{s}$ TNF $\alpha(P=0.06)$. (B) Effect of varying concentrations of TNF $\alpha$ on peak $L V \mathrm{~d} P / \mathrm{d} T$. In comparison with control values, there was a significant difference in peak $\mathrm{d} P / \mathrm{d} T$ for $50 \mathrm{U} / \mathrm{s}$ TNF $\alpha(P<0.03)$, but not for diluent $(P=0.08)$ or 10 $\mathrm{U} / \mathrm{s}$ TNF $\alpha(P=0.63)$. Of note, pretreatment with $100 \mu \mathrm{M} \mathrm{N}^{\mathrm{G}}$ nitro-L-arginine $(60 \mathrm{~min})$ did not block the negative inotropic effects of TNF $\alpha .{ }^{*} P<0.05$ in comparison with control values.

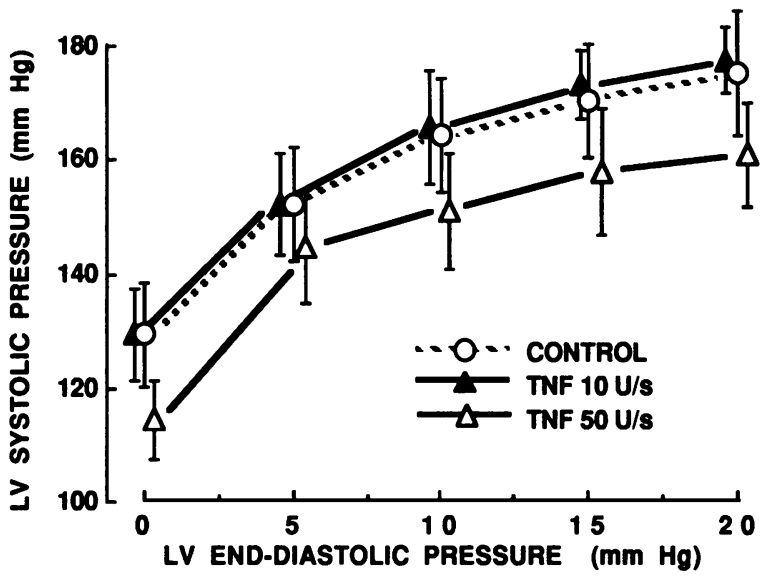

Figure 2. Effect of changes in preload on LV function ( $n=5$ hearts). For each increase in LV end-diastolic pressure there was the expected increase in LV systolic pressure after treatment with diluent or TNF $\alpha$. However, relative to the curves for diluent and $10 \mathrm{U} / \mathrm{s}$ TNF $\alpha$, the curve for $50 \mathrm{U} / \mathrm{s}$ of TNF $\alpha$ was shifted downward significantly ( $P$ $<0.04$ ), suggesting a decrease in LV contractility.

cantly different from control for $50 \mathrm{U} / \mathrm{s} \mathrm{TNF} \alpha(P<0.001)$, but not from control for $10 \mathrm{U} / \mathrm{s}$ TNF $\alpha(P=0.08)$. Two additional aspects of this study deserve further mention. First, once set at $10 \mathrm{mmHg}$ at the beginning of each protocol, $\mathrm{LV}$ end-diastolic did not change significantly $(P>0.35$ for each) during each of the 30 -min infusions with either diluent or 10 or 50 $\mathrm{U} / \mathrm{s}$ of TNF $\alpha$. Second, coronary artery perfusion pressure once set at $75 \mathrm{mmHg}$ did not change significantly during each of the 30 -min infusions $(P<0.95)$. Finally, to address the question of the reversibility of TNF $\alpha$-induced effects, each heart was again perfused with diluent for an additional $30 \mathrm{~min}$. This study showed that the final values for peak developed pressure and peak $\mathrm{d} P / \mathrm{d} T$ were not significantly different from control values $(P>0.75$ for both) by the end of the 30 -min wash-out period.

Fig. 2 shows the effect of changes in preload on $\mathrm{LV}$ function in the presence and absence of TNF $\alpha(10$ or $50 \mathrm{U} / \mathrm{s})$. At the end of each 25 -min period of continuous perfusion with either diluent or TNF $\alpha, L V$ end-diastolic pressure was increased incrementally from 0 to $20 \mathrm{mmHg}$ in order to construct a family of $\mathrm{LV}$ function curves. As expected, there was an increase in $\mathrm{LV}$ developed pressure with each increase in $\mathrm{LV}$ end-diastolic pressure (Fig. 2). However, the important finding shown by this figure is that, relative to the curves for diluent and $10 \mathrm{U} / \mathrm{s}$ TNF $\alpha$, the curve for $50 \mathrm{U} / \mathrm{s}$ of TNF $\alpha$ was shifted downward, suggesting that there was a decrease in LV contractile function with the higher concentration of cytokine. Two-way analysis of variance showed that there was no significant difference in peak developed pressure when comparing the curves for diluent and $10 \mathrm{U} / \mathrm{s}$ TNF $\alpha(P=0.86)$; there was, however, a significant difference when comparing the curves for diluent and 50 $\mathrm{U} / \mathrm{s}$ TNF $\alpha(P<0.04)$.

\section{Cardiocyte evaluation}

Cardiocyte viability. To be certain that the effects of TNF $\alpha$ were not secondary to cellular toxicity, as has been reported for some cell lines (23), we measured four indices of cardiocyte viability: the percentage of rod-shaped cells, the percentage of cells excluding trypan blue, creatine kinase release into the me- 
dium, and the presence or absence of nucleosome laddering (23). After $6 \mathrm{~h}$ of exposure, there was no significant $(P>0.05)$ decline in the percentage of viable rod-shaped cells for cells treated with $200 \mathrm{U} / \mathrm{ml}$ of TNF $\alpha(65 \pm 2 \%)$ in comparison with diluent-treated cells $(64 \pm 3 \%)$. Moreover, virtually all rodshaped cells treated with $200 \mathrm{U} / \mathrm{ml}$ TNF $\alpha$ excluded trypan blue. Finally, creatine kinase release was not significantly different in the cultures of control and TNF $\alpha$-treated cells $(86 \pm 16$ vs. $80 \pm 23 \mathrm{IU} / \mathrm{ml}$, respectively; $P>0.05$ ). Fig. 3 shows that for cells treated with diluent (lane 2) and $200 \mathrm{U} / \mathrm{ml} \mathrm{TNF} \alpha$ (lane 1), the DNA samples appear as sharp bands at the top of the gel, indicating that the DNA was intact, as opposed to fragmented. Thus, under the experimental conditions described herein, TNF $\alpha$ did not lead to either necrotic or apoptotic cell death.

Cardiocyte contractility. Fig. 4 summarizes the studies wherein the extent of cardiocyte shortening was examined for cells treated with concentrations of TNF $\alpha$ ranging from 50 to $200 \mathrm{U} / \mathrm{ml}$. As shown, there was an inverse relationship between the concentration of TNF $\alpha$ used and the extent of cardiocyte shortening. Analysis of variance indicated that these overall changes were significant statistically $(P<0.001)$; multiple comparison testing indicated there were significant differences from control for TNF $\alpha$ concentrations $\geq 100 \mathrm{U} / \mathrm{ml}$. Table I shows that there was a similar significant $(P<0.001)$ decrease in the velocity of cardiocyte shortening as a function of increasing concentration of TNF $\alpha$. The specificity of the TNF $\alpha$-induced effects was confirmed in the studies wherein an anti-human TNF $\alpha$ antibody was used to neutralize the effects of TNF $\alpha$. As shown in Fig. 4, $1.0 \mu \mathrm{l} / \mathrm{ml}$ of neutralizing antibody effectively attenuated the negative effects of TNF $\alpha$ ( $P$ $=0.61$ in comparison with control) on cell shortening.

To determine the time course of the TNF $\alpha$-induced negative inotropic effects, we examined cell motion at 5, 10, 15, 20, and $25 \mathrm{~min}$ after treatment with TNF $\alpha$. This analysis showed that while a decrease in cardiocyte shortening was evident within 5 min of treatment $(\sim 14 \%)$, the TNF $\alpha$-induced changes were not significantly different from control until 10 min after treatment $(P<0.001)$; no further significant reduction in cell motion was observed beyond 10 min of treatment with TNF $\alpha$. The question of the reversibility of the TNF $\alpha$ induced contractile defect was addressed by first treating the cells with $200 \mathrm{U} / \mathrm{ml}$ of TNF $\alpha$, and then washing the cultures

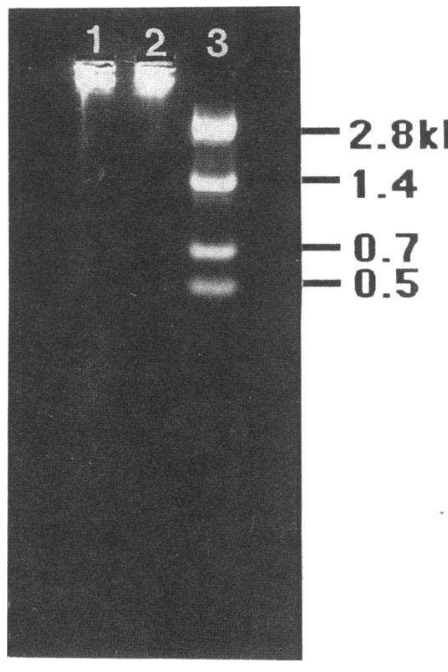

Figure 3. Effect of TNF $\alpha$ on nucleosome laddering. Lane 1 shows the DNA isolated from TNF $\alpha$ treated cardiocytes; lane 2 shows the DNA isolated diluent treated cells; lane 3 shows the DNA molecular weight ladder. Note the appearance of the sharp bands at the top of the gel for both diluent and TNF $\alpha$-treated cells, indicating that the DNA was intact, as opposed to fragmented.

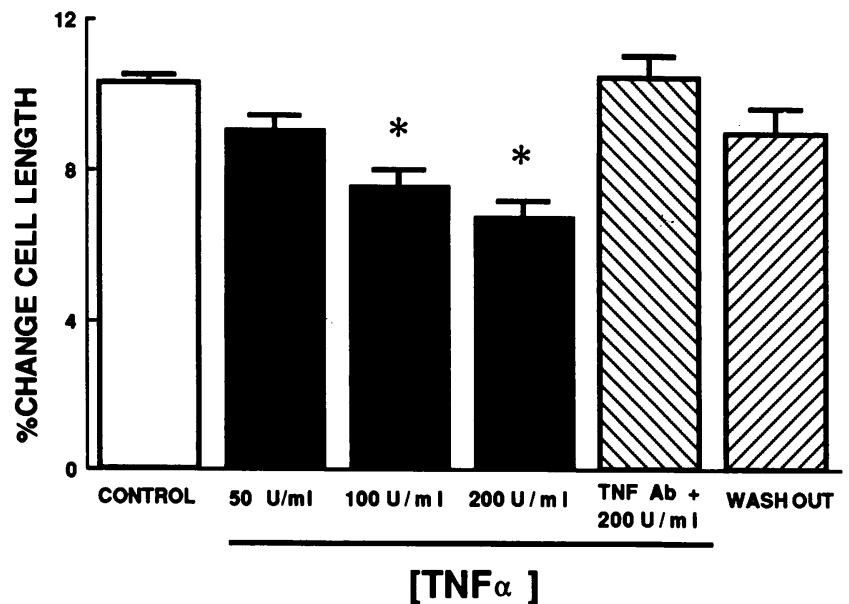

Figure 4. Effect of TNF $\alpha$ on cardiocyte shortening. In comparison with control (open bar) cardiocytes $(n=50)$, treatment with TNF $\alpha$ (closed bars; $n=\geq 25$ cells per group) resulted in a concentrationdependent decrease in cell shortening when studied at $37^{\circ} \mathrm{C}$. Pretreatment with a neutralizing anti-TNF $\alpha$ antibody (hatched bar; $n$ $=10$ cells) attenuated the effects of $200 \mathrm{U} / \mathrm{ml} \mathrm{TNF} \alpha$ on cell shortening. When the cells were washed free of $200 \mathrm{U} / \mathrm{ml} \mathrm{TNF} \alpha$ and allowed to recover for $45 \mathrm{~min}$, the effects of TNF $\alpha$ were completely reversible (hatched bar). Additional studies (not shown) indicated that treatment with $10 \mathrm{U} / \mathrm{ml}$ of TNF $\alpha$ did not have any significant effect on cardiocyte shortening, whereas treatment with $300 \mathrm{U} / \mathrm{ml} \mathrm{TNF} \alpha$ did not produce any further reduction in cardiocyte shortening over that observed with $200 \mathrm{U} / \mathrm{ml}$ TNF $\alpha$. Moreover, we found a similar significant decrease in cell shortening $(P<0.032)$ after treatment with $200 \mathrm{U} / \mathrm{ml}$ of TNF $\alpha$, when the cells were studied at $24^{\circ} \mathrm{C} .{ }^{*} P<0.05$ in comparison with control values.

three times before allowing the cells to recover ( $45 \mathrm{~min}$ ). As shown in Fig. 4, the effects of $200 \mathrm{U} / \mathrm{ml} \mathrm{TNF} \alpha$ were no longer evident after $45 \min (P=0.06$ compared with control $)$.

\section{Cellular basis for the effect of TNF $\alpha$ on cardiocyte contractility}

Calcium homeostasis. To determine whether the TNF $\alpha$-induced contractile defect was the result of a defect in calcium activation of the cells, cardiocytes were exposed to graded concentrations of superfusate calcium, ranging from 1.0 to 7.5 $\mathrm{mM}$, either in the presence $(200 \mathrm{U} / \mathrm{ml})$ or absence of TNF $\alpha$. Fig. 5 shows that for each calcium concentration examined, the extent of cardiocyte shortening was substantially depressed for the TNF $\alpha$ treated cells. Two-way analysis of variance showed that there were significant differences both within $(P<0.001)$ and between groups $(P<0.001)$, suggesting that treatment with TNF $\alpha$ led to altered calcium responsivity of the cell. Next, to determine whether this alteration was secondary to changes in calcium homeostasis, we examined intracellular calcium transients during cardiocyte contraction. Fig. 6 shows a typical time-intensity curve for fluorescence brightness in control and TNF $\alpha$-treated cardiocytes, both driven at $0.2 \mathrm{~Hz}$. Note that for the control cardiocyte, fluorescence brightness increased rapidly after electrical stimulation and then decreased gradually in a monotonic fashion. However, the salient finding shown by Fig. 6 is that for the TNF $\alpha$-treated cell, peak fluorescence brightness was substantially decreased, suggesting that peak $\left[\mathrm{Ca}^{2+}\right]_{\mathrm{i}}$ was decreased in the TNF $\alpha$-treated cell. The inset of Fig. 6 summarizes the results for the studies, wherein the peak fluorescence brightness was examined for groups of control 
Table I. Velocity of Cardiocyte Shortening in the Presence and Absence of TNF $\alpha$

\begin{tabular}{|c|c|c|c|c|c|}
\hline & \multicolumn{5}{|c|}{$\mathrm{TNF} \alpha(\mathrm{U} / \mathrm{ml})$} \\
\hline & $\begin{array}{l}\text { Diluent } \\
(n=50)\end{array}$ & $\begin{array}{c}50 \\
(n=25)\end{array}$ & $\begin{array}{c}100 \\
(n=30)\end{array}$ & $\begin{array}{c}200 \\
(n=30)\end{array}$ & $\begin{array}{c}200+\mathrm{Ab} \\
(n=10)\end{array}$ \\
\hline $\begin{array}{l}\text { Velocity of } \\
\text { shortening }(\mu \mathrm{m} / \mathrm{s})\end{array}$ & $69.8 \pm 3.7$ & $58.5 \pm 8.3$ & $44.5 \pm 4.1^{*}$ & $38.5 \pm 2.7^{*}$ & $74.2 \pm 6.7$ \\
\hline
\end{tabular}

Data are expressed as the mean \pm SEM. The peak velocity of cell shortening was determined for cardiocytes in the presence and absence of TNF $\alpha$, or in the presence of $200 \mathrm{U} / \mathrm{ml} \mathrm{TNF} \alpha$ preincubated with $1.0 \mu \mathrm{l} / \mathrm{ml}$ of neutralizing anti-TNF $\alpha$ antibody (Ab). Analysis of variance showed that there was a significant decrease in the velocity of cell shortening for the cardiocytes exposed to increasing concentrations of TNF $\alpha(P<0.001)$; post-hoc analysis of variance testing indicated that these changes were significantly different from control beyond $100 \mathrm{U} / \mathrm{ml} \mathrm{TNF} \alpha\left({ }^{*} P<0.01\right.$ compared with control values). Neutralizing anti-TNF $\alpha$ antibody alone had no effect on the extent or velocity of cardiocyte shortening.

and TNF $\alpha$-treated cells. Note that overall, there was $\sim 40 \%$ decrease in the percent change in peak intensity of fluorescence brightness for the TNF $\alpha$-treated cells in comparison with the control cardiocytes $(P<0.001)$. As an additional control for the above studies in populations of cells, we examined fluo-3 brightness in the same cell $(n=15)$, before and after treatment with TNF. This study showed that peak intracellular fluorescent brightness was $\sim 40 \%$ less for the same cell after treatment with TNF ( $1,631 \pm 126$ vs. $647 \pm 64.4 \mathrm{U} ; P=0.001)$; again baseline intracellular brightness was similar before ( $229 \pm 36.7 \mathrm{U})$ and after treatment with TNF $(205.4 \pm 35.6 ; P=0.66)$. Thus, taken together, these studies suggest that treatment with TNF $\alpha$ resulted in decreased peak levels of intracellular calcium during cardiocyte contraction.

Finally, to determine whether the TNF $\alpha$-induced alterations in cardiocyte contractility were secondary to alterations in cross bridge activation, we examined the extent of maximal cell shortening during tetanus of TNF $\alpha$-treated $(n=15)$ and control $(n=15)$ cardiocytes. This study showed that, under experimental conditions wherein levels of myoplasmic calcium

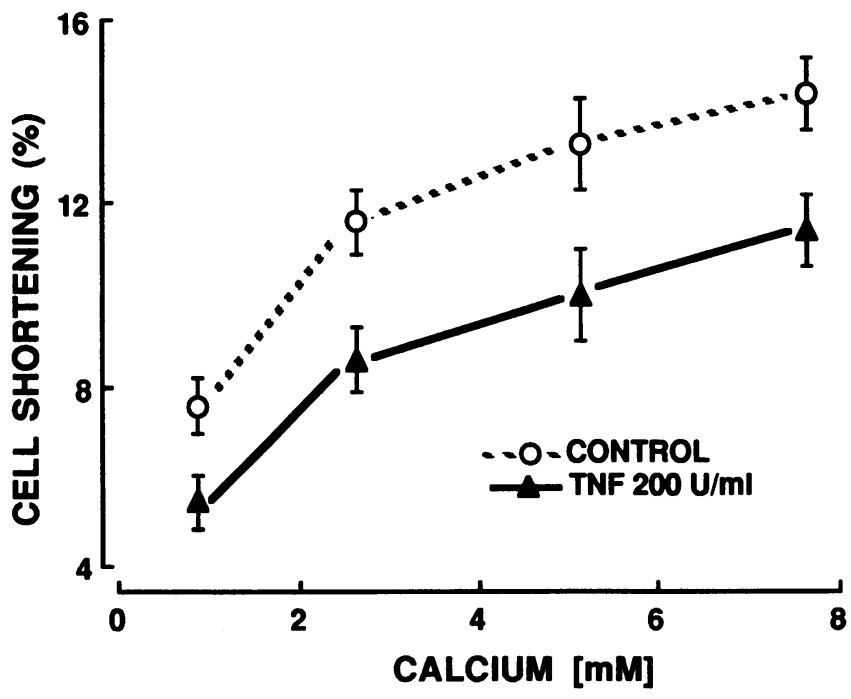

Figure 5. Effect of superfusate calcium on TNF $\alpha$-induced contractile dysfunction. Cardiocytes were incubated with diluent ( $n=35$ cells) or $200 \mathrm{U} / \mathrm{ml} \mathrm{TNF} \alpha(n=35$ cells $)$ for $30 \mathrm{~min}$ and the extent of cellular shortening determined for graded calcium concentrations ranging from 1 to $7.5 \mathrm{mM}$. As shown for each calcium concentration examined, the extent of cardiocyte shortening was significantly depressed $(P<0.001)$ for the TNF $\alpha$-treated cells. are elevated and which result in constant activation of the cross-bridges, there was no significant difference in the maximal extent of cell shortening between TNF $\alpha$-treated (200 U/ $\mathrm{ml})$ and control cardiocytes $(21.0 \pm 1.1 \%$ vs. $20.7 \pm 1.2 \%$, respectively; $P=0.86$ ).

Electrophysiology. To determine whether the above alterations in calcium homestasis were secondary to changes in the inward calcium current, we used the whole-cell patch-clamp technique to measure the current voltage relationship in isolated cardiac myocytes. Fig. 7 summarizes the results of the patch-clamp studies in isolated cardiac myocytes. Panel $A$ shows the superimposed currents elicited in a cardiac myocyte in response to voltage steps to - 20 (upper tracing), 0 (middle tracing), and $+20 \mathrm{mV}$ under baseline conditions and after treatment with $200 \mathrm{U} / \mathrm{ml} \mathrm{TNF} \alpha$ for $15 \mathrm{~min}$. As shown, the inward currents were virtually unchanged after treatment with TNF $\alpha$. The current-voltage relationships for group data ( $n$ $=12$ cells) are summarized in panel $B$. As shown, the overlap for the current-voltage relationship was considerable after treatment with $200 \mathrm{U} / \mathrm{ml} \mathrm{TNF} \alpha$. Two-way analysis of variance indicated that the current voltage relationship for TNF $\alpha$ treated cells was not significantly different from that obtained under baseline conditions $(P=0.39)$; moreover, there was no significant difference in the magnitude $(P=0.54)$ of the peak inward calcium current after treatment with TNF $\alpha$. Thus, treatment with TNF $\alpha$ did not to lead to significant differences in the current-voltage relationship or magnitude of the inward calcium current in isolated cardiac myocytes. This statement notwithstanding, it should be recognized that a potential limitation of the whole-cell patch-clamp technique is that electrolyte solutions contained within the patch electrode may exchange freely with the intracellular contents of the cell (37). Thus, we cannot completely discount the possibility that, under the experimental conditions used herein, TNF $\alpha$ might have had a small second-messenger-mediated effect on ion flux that was not evident because of intracellular dilutional effects arising from the patch electrode.

\section{Molecular basis for the effect of TNFa on cardiocyte contractility}

To determine the molecular basis for the TNF $\alpha$-induced effects on cardiocyte function, a series of five experiments were performed. Table II summarizes the first of three important findings with respect to the potential role of nitric oxide in terms of mediating the TNF $\alpha$-induced effects on cardiocyte contractility. As shown, pretreatment for $1 \mathrm{~h}$ with two different inhibitors of nitric oxide synthase, $N^{G}$-methyl-L-arginine and $N^{G}$-ni- 


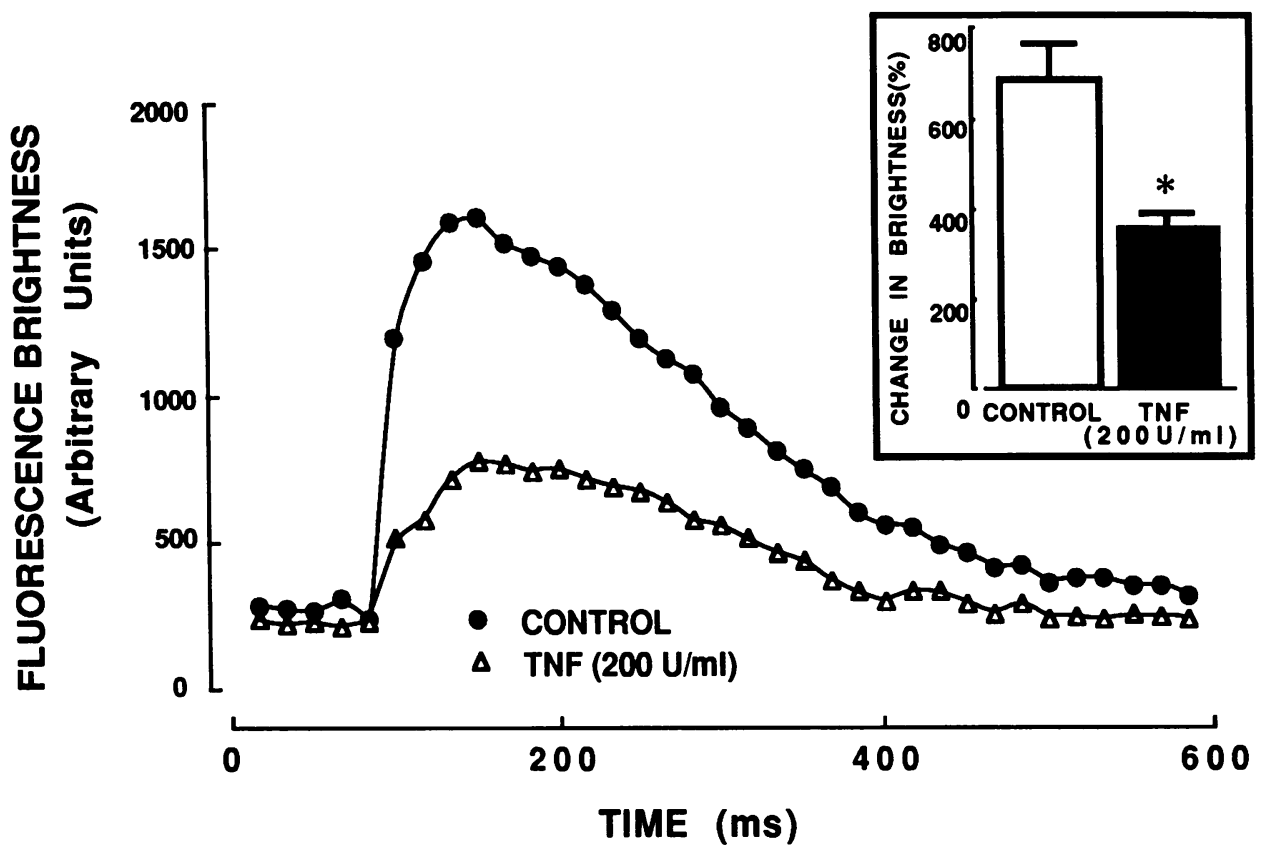

Figure 6. Time-intensity curve for fluorescence brightness. Control cells are shown by open circles and TNF $\alpha$-treated ( $200 \mathrm{U} / \mathrm{ml}$ ) cardiocytes by closed triangles. The peak level of intracellular fluorescence brightness was reduced strikingly for the cells treated with $200 \mathrm{U} / \mathrm{ml}$ TNF $\alpha$. The inset of this figure, which depicts values obtained for group data ( $n=35$ cells per group), shows that there was $\sim 40 \%$ decrease in the percent change in peak intensity of fluorescence brightness for the TNF $\alpha$-treated cells ( $P$ $<0.001$ ). Importantly, the basal levels of intracellular fluorescence brightness were similar $(P=0.20)$ for the control (225 \pm 34 arbitrary units) and TNF $\alpha$-treated cells $(291 \pm 38$ arbitrary units). To further confirm these findings in populations of cells, we examined fluo-3 brightness in the same cell $(n=15)$ before and after treatment with TNF $\alpha$. This study showed that peak intracellular fluorescent brightness was $\sim 40 \%$ less for the same cell after treatment with TNF $\alpha(1,631 \pm 126$ vs. $647 \pm 64.4 U ; P=0.001)$; again baseline intracellular brightness was similar both before $(229 \pm 36.7 U)$ and after treatment with TNF $\alpha(205.4 \pm 35.6 ; P=0.66)$. Finally, in control experiments we observed that there was no significant difference $(P=$ $0.19)$ in the peak intracellular fluorescent brightness in digitonin permeabilized cardiac myocytes either in the presence $(n=51$ cells $)$ or absence ( $n=44$ cells) of TNF $\alpha$, thus suggesting that this cytokine did not interfere with the emission strength of the fluo-3 signal.

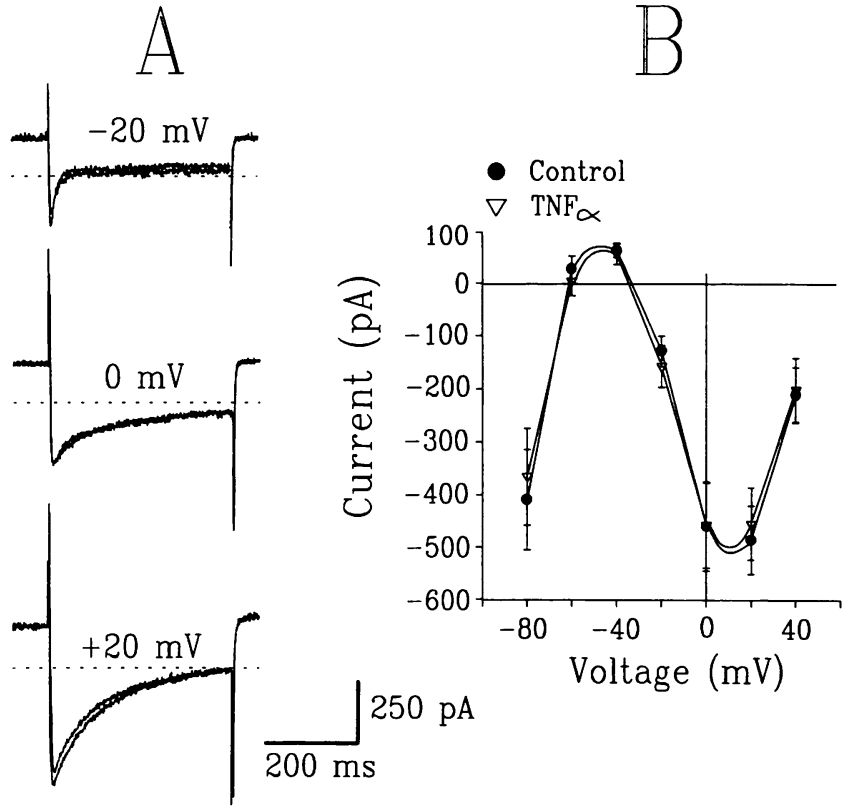

Figure 7. Whole-cell patch-clamp studies in the presence and absence of TNF $\alpha$. $(A)$ Currents elicited in a cardiac myocyte in response to voltage steps to -20 ( upper tracing), 0 (middle tracing), and $+20 \mathrm{mV}$ (lower tracing) under baseline conditions and after 15 min of treatment with TNF $\alpha$. As shown, the inward currents were unchanged after treatment with TNF $\alpha$. (B) Current-voltage relationships for group data ( $n=12$ cells). There was no change in the current-voltage relationship after treatment with TNF $\alpha(P=0.39)$; moreover, there was no significant difference in the magnitude $(P=0.54)$ of the peak inward calcium current.
tro-L-arginine, did not significantly attenuate the negative inotropic effects of $200 \mathrm{U} / \mathrm{ml}$ of TNF $\alpha$. A second line of evidence against a role for nitric oxide in mediating the effects of TNF $\alpha$ was provided by studies wherein levels of breakdown products of nitric oxide were measured. This study showed that there was no increase in nitrite levels (nanograms of nitrite per milligram of cardiocyte protein) after $30 \mathrm{~min}$ (control $=46.8 \pm 8.7$ [ $n=10$ dishes $]$ vs TNF $\alpha=45.0 \pm 7.6[n=10$ dishes $] ; P$ $=0.87$ ) or $6 \mathrm{~h}$ (control $=142.3 \pm 18.0[n=10$ dishes $]$ vs TNF $\alpha$ $=98.9 \pm 12.1$ [ $n=10$ dishes]; $P=0.06$ ) of treatment with 200 $\mathrm{U} / \mathrm{ml} \mathrm{TNF} \alpha$. A third line of evidence against a role for nitric oxide in terms of mediating the negative inotropic effects of TNF $\alpha$ is given in Table III. The important finding shown by this table is that there was no significant $(P=0.16)$ difference between control and TNF $\alpha$ treated cells with respect to cGMP production over the period of study. In contrast, treatment with sodium nitroprusside led to an eightfold $(P<0.001)$ increase (compared with control values at $0 \mathrm{~min}$ ) in cardiocyte cGMP levels at $15 \mathrm{~min}$. Table II summarizes the remaining series of studies designed to determine the molecular basis for the TNF $\alpha$-induced effects on cardiocyte contractility. Pretreating the cells with concentrations of indomethacin or hydrocortisone that have been shown to be effective in terms of attenuating the effects of TNF $\alpha$ in other cell types $(34,35,38)$, or a concentration of cycloheximide that has been shown to suppress protein synthesis completely in feline cardiocytes (19), did not significantly antagonize the effects of TNF $\alpha$ on cardiocyte contractility. Moreover, pretreating the cells with a broad range of concentrations of TGF $\beta$ also did not attenuate the negative inotropic effects of TNF $\alpha$. 


\section{Discussion}

This study, in which the effects of TNF $\alpha$ were studied systematically in the intact LV and the isolated cardiac myocyte, shows for the first time that the negative inotropic effects of TNF $\alpha$ are the direct result alterations in intracellular calcium homeostasis in the adult cardiac myocyte. This conclusion is supported by the following lines of evidence. First, when intact hearts were treated with TNF $\alpha$, we observed a concentration- and time-dependent negative inotropic effect (Figs. 1 and 2) which was fully reversible after removing TNF $\alpha$ from the superfusate. Second, when isolated adult cardiac myocytes were treated with TNF $\alpha$, we observed a similar concentration- and time-dependent negative inotropic effect (Fig. 4, Table I) that also was fully reversible upon removing this cytokine from the superfusate. It is noteworthy that the effects of TNF $\alpha$ observed in isolated cardiac myocytes were not only qualitatively similar to those found in the intact heart, in that the cytokine-induced effects were concentration- and time-dependent in both preparations, but they were also quantitatively similar as well. Indeed, both the time to onset of the TNF $\alpha$-induced negative inotropic effects $(\sim 15-20 \mathrm{~min})$ and the concentration of TNF $\alpha$ necessary to produce the negative inotropic effects $(\sim 90-100 \mathrm{U} / \mathrm{ml})$, were similar in the intact heart and the isolated cardiac myocyte. Third, the data suggest that the negative inotropic effects of TNF $\alpha$ are the direct result of alterations

Table II. Molecular Basis for the Effects of TNF $\alpha$ on Cardiocyte Contractility

\begin{tabular}{lc}
\hline \multicolumn{1}{c}{$200 \mathrm{U} / \mathrm{ml} \mathrm{TNF} \alpha$} & Percent change from control \\
\hline $\mathrm{N}^{\mathrm{G}}$-methyl-L-arginine & \\
$10 \mu \mathrm{M}(n=10)$ & $-21.5 \pm 4.7^{\ddagger}$ \\
$100 \mu \mathrm{M}(n=10)$ & $-19.6 \pm 2.7^{\ddagger}$ \\
$1,000 \mu \mathrm{M}(n=10)$ & $-23.9 \pm 4.7^{\ddagger}$ \\
$\mathrm{N}^{\mathrm{G}}$-nitro-L-arginine & \\
$10 \mu \mathrm{M}(n=10)$ & $-20.6 \pm 5.6^{\ddagger}$ \\
$100 \mu \mathrm{M}(n=10)$ & $-24.5 \pm 6.1^{*}$ \\
$1,000 \mu \mathrm{M}(n=10)$ & $-24.5 \pm 3.1^{*}$ \\
$\mathrm{TGF} \beta$ & \\
$1 \mathrm{ng} / \mathrm{ml}(n=15)$ & $-18.0 \pm 6.7^{*}$ \\
$10 \mathrm{ng} / \mathrm{ml}(n=15)^{\S}$ & $-22.3 \pm 6.2^{*}$ \\
$100 \mathrm{ng} / \mathrm{ml}(n=15)$ & $-17.4 \pm 5.2^{*}$ \\
Cycloheximide $10^{-5} \mathrm{M}(n=10)$ & $-20.8 \pm 4.8^{\ddagger}$ \\
Hydrocortisone $10^{-6} \mathrm{M}(n=10)^{\S}$ & $-25.6 \pm 6.3^{\ddagger}$ \\
Indomethacin $100 \mu \mathrm{M}(n=24)$ & $-15.0 \pm 4.2^{\ddagger}$ \\
\end{tabular}

Data are expressed as the mean \pm SEM values of the percent change from control values (mean). The extent of cell shortening was determined for cardiocytes after pretreatment with the above agents, either in the presence or absence of $200 \mathrm{U} / \mathrm{ml} \mathrm{TNF} \alpha$. Data were compared by $t$ test. As shown pretreatment of the cardiocytes for $1 \mathrm{~h}$ with $\mathrm{N}^{\mathrm{G}}$ methyl-L-arginine, $\mathrm{N}^{\mathrm{G}}$-nitro-L-arginine, TGF $\beta$, cycloheximide, hydrocortisone, or indomethacin did not significantly attenuate the negative inotropic effects of TNF $\alpha$. Further, pretreatment of the cells for $5 \mathrm{~h}$ (shown by section mark [\$] above) with $10 \mathrm{ng} / \mathrm{ml}$ of TGF $\beta$ or with $10^{-6} \mathrm{M}$ hydrocortisone did not significantly attenuate negative inotropic effects of TNF $\alpha(200 \mathrm{U} / \mathrm{ml})$ when compared with control $\left(10 \mathrm{ng} / \mathrm{ml} \mathrm{TGF} \beta=-16.2 \pm 5.8 \%[P=0.032] ; 10^{-6} \mathrm{M}\right.$ hydrocortisone $=-16.0 \pm 4.1 \%[P=0.03]) . n$, number of cells per experimental group; control groups contained an identical number of cells. ${ }^{*} P$ $<0.01 ;{ }^{\ddagger} P .<0.05$.
Table III. Cardiocyte Cyclic GMP Levels after Stimulation with $T N F \alpha$

\begin{tabular}{|c|c|c|c|}
\hline & \multicolumn{3}{|c|}{$\begin{array}{c}\text { Stimulation } \\
\text { min }\end{array}$} \\
\hline & 0 & 15 & 30 \\
\hline & \multicolumn{3}{|c|}{ 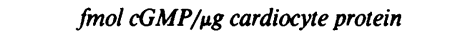 } \\
\hline Control (diluent) & $3.1 \pm 1.1$ & $4.0 \pm 1.2$ & $6.0 \pm 0.8$ \\
\hline $\mathrm{TNF} \alpha(200 \mathrm{U} / \mathrm{ml})$ & $4.2 \pm 3.1$ & $5.2 \pm 1.2$ & $8.9 \pm 1.9$ \\
\hline Nitroprusside $(100 \mu \mathrm{M})$ & - & $26.5 \pm 2.3^{*}$ & - \\
\hline
\end{tabular}

Data are mean \pm SEM values ( $n=5$ cultures for each time point). Stimulation of cardiocyte cultures with $200 \mathrm{U} / \mathrm{ml} \mathrm{TNF} \alpha$ did not result in a significant increase in cardiocyte cGMP when examined from 0 to $30 \mathrm{~min}$. Analysis of variance showed that there were no significant differences in cGMP levels between $(P=0.16)$ groups. In contrast, $100 \mu \mathrm{M}$ nitroprusside resulted in eightfold increase in cGMP at $15 \mathrm{~min}$ in comparison with control values obtained at $0 \mathrm{~min}(P$ $<0.001)$. Examination of earlier time points $(5 \mathrm{~min})$ did not reveal significant differences between control and TNF $\alpha$-treated cells. ${ }^{*} P$ $<0.001$.

in intracellular calcium homeostasis. This conclusion is based upon the digital imaging microscopy studies wherein treatment with TNF $\alpha$ led to a striking decrease in peak intracellular fluorescence during the systolic contraction sequence (Fig. 6), as well as the myocyte tetanization studies which showed that the negative inotropic effects of TNF $\alpha$ were abolished by repetitively stimulating the cross-bridges in the presence of elevated levels of myoplasmic calcium (20). Thus, under experimental conditions that restore depressed levels of intracellular calcium, one is able to overcome the negative inotropic effects of TNF $\alpha$.

Although we cannot exclude subtle alterations in myofilament sensitivity as a potential mechanism for the negative inotropic effects of TNF $\alpha$, the data summarized in Fig. 5 are not consistent with this point of view. That is, if treatment with $\mathrm{TNF} \alpha$ altered myofilament sensitivity to calcium, we would have predicted that the extent of shortening in the TNF $\alpha$ treated cells, while depressed at lower calcium concentrations, would become similar to values obtained in control cells as the superfusate calcium concentration was increased. However, as shown in Fig. 5, we observed that the magnitude of the difference in cardiocyte shortening remained constant between control and TNF $\alpha$-treated cells, despite using a broad range of calcium concentrations. Finally, it should be emphasized that none of the effects of TNF $\alpha$ on myocardial or cellular function could be attributed to a cytokine-induced decrease in cardiac myocyte viability, inasmuch as there was no evidence for necrosis or apoptosis (Fig. 3) in cardiocyte cultures treated with $\mathrm{TNF} \alpha$; moreover, all of the TNF $\alpha$-induced effects were completely reversible with time.

Effects of TNF $\alpha$ on myocardial function. In examining the general point of view that TNF $\alpha$ adversely affects cardiovascular function, previous studies have shown that direct injections of TNF $\alpha$ in experimental animals produce hypotension, metabolic acidosis, hemoconcentration, and death within minutes to hours, thus mimicking the hemodynamic response seen during endotoxin-induced septic shock (39-42). Moreover, injections of antibodies raised against TNF $\alpha$ have been shown to attenuate the hemodynamic collapse seen in endotoxin shock 
(43). The importance of TNF $\alpha$ in the clinical setting has been suggested both by studies in which injection of endotoxin into humans resulted in elevations in TNF $\alpha$ and depressed LV ejection performance (8), as well as studies wherein TNF $\alpha$ infusions in patients undergoing antitumor therapy resulted in profound systemic hypotension (10-12).

In examining the more specific point of view that TNF $\alpha$ adversely affects myocardial function, previous studies employing rat neonatal myocyte preparations have shown that TNF $\alpha$ blunts the positive inotropic effect of isoproterenol after $72 \mathrm{~h}$ of exposure, but did not adversely affect baseline contractile function of these juvenile cells (44-46). In contrast, a very recent study in which thin strips of myocardial tissue (27) were exposed to graded concentrations of TNF $\alpha$ showed an immediate (2-3 $\mathrm{min}$ ) concentration-dependent decrease in myocardial contractility which was completely reversible upon removal of this cytokine. Finally, a series of in vivo studies in dogs showed that a single infusion of TNF $\alpha$ resulted in abnormalities of systolic and diastolic function within the first $24 \mathrm{~h}$ of infusion $(9,14,47)$. Of note, the most recent of these in vivo canine studies reported a time-dependent negative inotropic effect that was similar to the one observed in the present study (14). Thus, the cellular studies presented herein both confirm and expand upon previous in vivo and in vitro studies in myocardial tissue. While the precise reason(s) for the discrepant findings between the present study and the previous study in neonatal rat myocytes is not apparent (44-46), it is likely that the disparity may relate, at least in part, to one or more of the well-described developmental differences between neonatal and adult myocyte preparations $(48,49)$.

Mechanism(s) of $T N F \alpha$-induced contractile dysfunction. With respect to the potential mechanism(s) for TNF $\alpha$-induced contractile defects, a recent study in rat neonatal cells suggests that subacute ( $48 \mathrm{~h}$ ) exposure to TNF $\alpha$ leads to a G proteinmediated defect in $\beta$-adrenergic signal transduction (45). However, as noted above, these results in juvenile cells are quite different from those obtained in adult cells, and it is unlikely that the rapidity of the TNF $\alpha$-induced changes in baseline contractile function in the present study can be explained completely by the subacute changes in $G$ protein-mediated signal transduction.

A second more recent study in thin strips of myocardial tissue provided indirect evidence in support of the point of view that TNF $\alpha$-induced contractile dysfunction resulted from "enhanced activity of a constitutive nitric oxide synthase in the myocardium" (27). As shown, the results of the present study demonstrate that the TNF $\alpha$-induced abnormalities in contractile function can be explained by decreased levels of intracellular calcium during the systolic contraction sequence. While the exact molecular mechanism(s) for this abnormality in calcium homeostasis is not clear, three lines of evidence suggest that a change in the level of intracellular nitric oxide is unlikely to be responsible for the TNF $\alpha$-induced abnormality in intracellular calcium homeostasis. In accordance with previous studies by Moncado and coworkers (29), we were unable to detect any evidence for a TNF $\alpha$-induced increase in the level of constitutive nitric oxide, as measured by changes in the level of superfusate nitrite, the immediate oxidative breakdown product of nitric oxide (29), or significant changes in the level of cardiocyte cGMP ( Table III), the intracellular signalling pathway utilized by nitric oxide (29). Moreover, we were unable to attenuate the acute negative inotropic effects of TNF $\alpha$ with two different inhibitors of nitric oxide synthase, despite using a broad range of concentrations for each agent. Finally, under the experimental conditions used herein, we were unable to detect a potential role for arachidonic acid metabolites (34), or for de novo protein synthesis (33) in terms of mediating the contractile dysfunction induced by $\mathrm{TNF} \alpha$, nor a potential direct role for TGF $\beta$ in protecting the cardiocyte against TNF $\alpha$-mediated injury (5).

With respect to the potential mechanism(s) responsible for the TNF $\alpha$-induced alterations in calcium homeostasis, the electrophysiological data presented herein do not support a potential role for alterations in the voltage sensitive inward calcium current (Fig. 7) as a likely mechanism for the negative inotropic effects of TNF $\alpha$. Nonetheless, these negative data do at least serve the heuristic purpose of focusing future mechanistic studies on the effects of TNF $\alpha$ on sarcoplasmic reticular function. Indeed, given that the downward (diastolic) slopes of the calcium transients in control and the TNF $\alpha$-treated cells appear to be different (Fig. 6), it is quite possible that TNF $\alpha$ may in fact alter sarcoplasmic reticular function in the adult cardiac myocyte.

Conclusion. Given the well-recognized association between the elaboration of TNF $\alpha$ during sepsis and the hemodynamic collapse that has become the hallmark of this condition (40), it was not surprising to find that TNF $\alpha$ exerted direct negative inotropic effects in the intact heart. This statement notwithstanding, the importance of the present study is twofold. First, the study provides straightforward and compelling evidence that TNF $\alpha$ exerts its effects directly at the level of the adult cardiac myocyte, and not necessarily indirectly by releasing soluble factor(s) from nonmyocyte cell types residing within the myocardium. Second, this study provides direct evidence for a cellular mechanism for the TNF $\alpha$-induced contractile dysfunction. That is, treatment with TNF $\alpha$ led to alterations in intracellular calcium homeostasis that could explain the $\mathrm{TNF} \alpha$-induced alterations in contractile function completely. While direct correlations between short-term effects in isolated cells and long-term effects in the heart in vivo are not appropriate, these data do provide potential clinical insights into several cardiac disease states wherein elevated TNF $\alpha$ levels have been reported, including acute viral myocarditis (2), cardiac allograft rejection (3), subacute myocardial infarction $(4,5)$, and congestive heart failure $(6,7)$. Although it remains to be determined whether pro-inflammatory cytokines play a pathogenetic role in any of these conditions, the findings of this study would at least provide a potential cellular basis for the LV dysfunction that often occurs during the course of these pathophysiological conditions.

\section{Acknowledgments}

The authors gratefully acknowledge the technical expertise of Mr. Stan Bravenac and the secretarial assistance of Ms. Donna Espadas. We would also like to thank Drs. Mark Entman and Robert Roberts for their review of the manuscript and Dr. Diana Kunze for her invaluable assistance with the patch-clamp studies. Finally, we would like to thank both of the reviewers for their thoughtful criticisms of the manuscript.

This study was supported by grants K08HL-02010, HL-41408, and HL-42550 from the National Institutes of Health and by funds from the Department of Veterans Affairs. 


\section{References}

1. Carswell, E. A., L. J. Old, R. L. Kassel, S. Green, N. Fiore, and B. Williamson. 1975. An endotoxin-induced serum factor that causes necrosis of tumors. Proc. Natl. Acad. Sci. USA. 72:3666-3670.

2. Smith, S. C., and P. M. Allen. 1992. Neutralization of endogenous tumor necrosis factor ameliorates the severity of myosin-induced myocarditis. Circ. Res. 70:856-863.

3. Arbustini, E., M. Grasso, M. Diegoli, M. Bramerio, A. S. Foglieni, M. Albertario, L. Matinelli, A. Gavazzi, C. Goggi, C. Campana, et al. 1991. Expression of tumor necrosis factor in human acute cardiac rejection: an immunohistochemical and immunoblotting study. Am. J. Pathol. 139:709-715.

4. Maury, C. P. J., and A. M. Teppo. 1989. Circulating tumour necrosis factor- $\alpha$ (cachectin) in myocardial infarction. J. Intern. Med. 225:333-336.

5. Lefer, A. M., P. Tsao, N. Aoki, and M. A. Palladino, Jr. 1990. Mediation of cardioprotection by transforming growth factor- $\beta$. Science (Wash. DC). 249:6164.

6. Levine, B., J. Kalman, L. Mayer, H. M. Fillit, and M. Packer. 1990. Elevated circulating levels of tumor necrosis factor in severe chronic heart failure. $N$. Engl. J. Med. 223:236-241.

7. McMurray, J., I. Abdullah, H. J. Dargie, and D. Shapiro. 1991. Increased concentrations of tumour necrosis factor in "cachectic" patients with severe chronic heart failure. Br. Heart J. 66:356-358.

8. Suffredini, A. F., R. E. Fromm, M. M. Parker, M. Brenner, J. A. Kovacs, R. A. Wesley, and J. E. Parrillo. 1989. The cardiovascular response of normal humans to the administration of endotoxin. N. Engl. J. Med. 321:280-287.

9. Natanson, C., P. W. Eichenholz, R. L. Danner, W. Eichacker, D. Hoffman, S. M. Kuo, T. J. Banks, T. J. MacViottie, and J. E. Parrillo. 1992. Endotoxin and tumor necrosis factor challenges in dogs simulate the cardiovascular profile of human septic shock. J. Exp. Med. 169:823-832.

10. Spriggs, D. R., M. L. Sherman, H. Michie, K. A. Arthur, K. Imamura, D. Wilmore, E. Frei III., and D. W. Kufe. 1988. Recombinant human tumor necrosis factor administered as a 24-hour intravenous infusion: a phase I and pharmacologic study. J. Natl. Cancer Inst. 80:1039-1044.

11. Blick, M., S. A. Sherwin, M. Rosenblum, and J. Gutterman. 1987. Phase I study of recombinant tumor necrosis factor in cancer patients. Cancer. Res. 47:2986-2989.

12. Selby, P., S. Hobbs, C. Viner, E. Jackson, A. Jones, D. Newell, A. H Calvert, T. McElwain, K. Fearon, J. Humphreys, et al. 1987. Tumor necrosis factor in man: clinical and biological observations. Br. J. Cancer. 56:803-808.

13. Weglicki, W. B., T. M. Phillips, A. M. Freedman, M. M. Cassidy, and B. F. Dickens. 1992. Magnesium-deficiency elevates circulating levels of inflammatory cytokines and endothelin. Mol. Cell. Biochem. 110:169-173

14. Eichenholtz, P. W., P. Q. Eichacker, W. D. Hoffman, S. M. Banks, J. E Parrillo, R. L. Danner, and C. Natanson. 1992. Tumor necrosis factor challenges in canines: patterns of cardiovascular dysfunction. Am. J. Physiol. 263:H668H675.

15. Mickelson, J. K., P. J. Simpson, and B. R. Lucchesi. 1988. Myocardial dysfunction and coronary vasoconstriction induced by platelet-activating factor in the post-infarcted rabbit isolated heart. J. Mol. Cell. Cardiol. 20:547-561.

16. Jacobson, S. L. and H. M. Piper. 1986. Cell cultures of adult cardiomyocytes as models of the myocardium. J. Mol. Cell. Cardiol. 18:661-678.

17. Kleinman, R. B., and S. R. Houser. 1988. Calcium currents in normal and hypertrophied isolated feline ventricular myocytes. Am. J. Physiol. H1434 H1442.

18. Silver, L. H., and S. R. Houser. 1985. Transmembrane potassium fluxes in isolated feline ventricular myocytes. Am. J. Physiol. 248:H614-H621.

19. Mann, D. L., R. L. Kent, and G. Cooper. 1989. Load regulation of the properties of adult feline cardiocytes: growth induction by cellular deformation. Circ. Res. 64:1079-1090.

20. Mann, D. L., Y. Urabe, R. L. Kent, S. Vinciguerra, and G. Cooper. 1991. Cellular versus myocardial basis for the contractile dysfunction of hypertrophied myocardium. Circ. Res. 68:402-415.

21. Mann, D. L., R. L. Kent, B. Parsons, and G. Cooper. 1992. Adrenergic effects on the biology of the adult mammalian cardiocyte. Circulation. 85:790 804.

22. Steadman, B. W., K. B. Moore, K. W. Spitzer, and J. H. B. Bridge. 1988. A video system for measuring motion in contracting heart cells. IEEE Trans. Biomed. Eng. 35:264-272.

23. Larrick, J. W., and S. C. Wright. 1990. Cytotoxic mechanism of tumo necrosis factor- $\alpha$. FASEB. J. 4:3215-3223.

24. Aggarwal, B. B., W. J. Kohr, P. E. Hass, B. Moffat, S. A. Spencer, W. J. Henzel, T. S. Bringman, G. E. Nedwin, D. V. Goeddel, and R. N. Harkins. 1985. Human tumor necrosis factor: production, purification, and characterization. $J$. Biol. Chem. 260:2345-2354.
25. Blin, N., and D. W. Stafford. 1976. A general method for isolation of high molecular weight DNA from eukaryotes. Nucleic Acids Res. 3:2303-2308.

26. Vaca, L., W. P. Schilling, and D. L. Kunze. 1992. G-protein mediated regulation of $\mathrm{Ca}^{2+}$-dependent $\mathrm{K}^{+}$channel in cultured vascular endothelial cells. Pflügers Arch. Eur. J. Physiol. 422:66-74.

27. Finkel, M. S., C. V. Oddis, T. D. Jacob, S. C. Watkins, B. G. Hattler, and R. L. Simmons. 1992. Negative inotropic effects of cytokines on the heart mediated by nitric oxide. Science (Wash. DC). 257:387-389.

28. Kilbourn, R. G., S. S. Gross, A. Jubran, J. Adams, O. W. Griffith, R. Levi, and R. F. Lodato. $1990 . \mathrm{N}^{\mathrm{G}}$-methyl-L-arginine inhibits tumor necrosis factor-induced hypotension: implications for the involvement of nitric oxide. Proc. Natl. Acad. Sci. USA. 87:3629-3632.

29. Schulz, R., E. Nava, and S. Moncada. 1992. Induction and potential biological relevance of a $\mathrm{Ca}^{2+}$-independent nitric oxide synthase in the myocardium. Br. J. Pharmacol. 105:575-580.

30. Moncada, S., M. J. Palmer, and E. A. Higgs. 1991. Nitric oxide: physiology, pathophysiology, and pharmacology. Pharmacol. Rev. 43:109-142.

31. Schmidt, H. H., T. D. Warner, M. Nakane, U. Forstermann, and F. Murad. 1992. Regulation and subcellular location of nitrogen oxide synthases in RAW264.7 macrophages. J. Pharmacol. Exp. Ther. 41:615-624.

32. Smith, P. K., R. I. Krohn, G. T. Hermanson, A. K. Mallia, F. H. Gartner, M. D. Provenzano, E. K. Fujimoto, N. M. Goeke, D. C. Klenk, and B. J. Olson. 1985. Measurement of protein using bicinchoninic acid. Anal. Biochem. 150:7685.

33. Vilcek, J. and T. H. Lee. 1991. Tumor necrosis factor: new insights into the molecular mechanisms of its multiple actions. J. Biol. Chem. 266:7313-7316.

34. Bouchelouche, P. N., K. Bendtzen, S. Bak, and O. H. Nielsen. 1990. Recombinant human tumour necrosis factor increases cytosolic free calcium in murine fibroblasts and stimulates inositol phosphate formation in L-M and arachidonic acid release in 3T3 cells. Cell. Signalling. 2:479-487.

35. Kettelhut, I. C., W. Fiers, and A. L. Goldberg. 1987. The toxic effects of tumor necrosis factor in vivo and their prevention by cyclooxygenase inhibitors. Proc. Natl. Acad. Sci. USA. 84:4273-4277.

36. McKenna, T. M. 1990. Prolonged exposure of rat aorta to low levels of endotoxin in vitro results in impaired contractility, association with vascular cytokine release. J. Clin. Invest. 86:160-168.

37. Fenwick, E., A. Marty, and E. Neher. 1982. A patch-clamp study of bovine chromaffin cells and of their sensitivity to acetylcholine. J. Physiol. (Lond.). 331:577-597.

38. Hülsmann, W. C., and M.-L. Dubelaar. 1988. Effects of tumor necrosis factor (TNF) on lipolytic activities of rat heart. Mol. Cell. Biochem. 79:147-151.

39. Tracey, K. J., B. Beutler, S. F. Lowry, J. Merryweather, S. Wolpe, I. W. Milsark, R. J. Hariri, T. J. Fahey III, A. Zentella, J. D. Albert, et al. 1986. Shock and tissue injury induced by recombinant human cachectin. Science (Wash. DC). 234:470-474

40. Tracey, K. J., S. F. Lowry, T. J. Fahey III., J. D. Albert, Y. Fong, D. G. Hesse, B. Beutler, K. R. Manogue, S. Calvano, A. Cerami, and et al. 1987. Cachectin/tumor necrosis factor induces lethal shock and stress hormone responses in the dog. Surg. Gynecol. Obstet. 164:415-422.

41. Remick, D. G., R. G. Kunkel, J. W. Larrick, and S. L. Kunkel. 1987. Acute in vivo effects of human recombinant tumor necrosis factor. Lab. Invest. 56:583-590.

42. Gaskill, H. V., III. 1988. Continuous infusion of tumor necrosis factor: mechanisms of toxicity in the rat. J. Surg. Res. 44:664-671.

43. Tracey, K. J., Y. Fong, D. G. Hesse, K. R. Manogue, A. T. Lee, G. C. Kuo, S. F. Lowry, and A. Cerami. 1987. Anti-cachectin/TNF monoclonal antibodies prevent septic shock during lethal bacteraemia. Nature (Lond.). 330:662-664.

44. Gulick, T., M. K. Chung, S. J. Pieper, L. G. Lange, and G. F. Schreiner. 1989. Interleukin 1 and tumor necrosis factor inhibit cardiac myocyte $\beta$-adrenergic responsiveness. Proc. Natl. Acad. Sci. USA. 86:6753-6757.

45. Chung, M. K., T. S. Gulick, R. E. Rotondo, G. F. Schreiner, and L. G. Lange. 1992. Mechanism of action of cytokine inhibition of $\beta$-adrenergic agonist stimulation of cyclic AMP in rat cardiac myocytes: impairment of signal transduction. Circ. Res. 1990:753-763.

46. Gulick, T., J. S. Pieper, M. A. Murphy, L. G. Lange, and G. F. Schreiner. 1991. A new method for assessment of cultured cardiac myocyte contractility detects immune factor-mediated inhibition of $\beta$-adrenergic responses. Circulation. 84:313-321.

47. Pagani, F. D., L. S. Baker, C. Hsi, M. Knox, M. P. Fink, and M. S. Visner. 1992. Left ventricular systolic and diastolic dysfunction after infusion of tumor necrosis factor- $\alpha$ in conscious dogs. J. Clin. Invest. 90:389-398.

48. Claycomb, W. C. 1982 . Ultrastructure of terminally differentiated adult rat cardiac muscle cells in culture. Am. J. Anat. 164:113-131.

49. Claycomb, W. C. 1983. Cardiac muscle cell proliferation and cell differentiation in vivo and vitro. Adv. Exp. Med. Biol. 161:249-265. 